Man and Nature

L'homme et la nature

\title{
Gulliver Shifts for Himself
}

Mark Madoff

Volume 3, 1984

URI : https://id.erudit.org/iderudit/1011824ar

DOI : https://doi.org/10.7202/1011824ar

Aller au sommaire du numéro

Éditeur(s)

Canadian Society for Eighteenth-Century Studies / Société canadienne d'étude du dix-huitième siècle

ISSN

0824-3298 (imprimé)

1927-8810 (numérique)

Découvrir la revue

Citer cet article

Madoff, M. (1984). Gulliver Shifts for Himself. Man and Nature / L'homme et la nature, 3, 47-62. https://doi.org/10.7202/1011824ar

Copyright $@$ Canadian Society for Eighteenth-Century Studies / Société canadienne d'étude du dix-huitième siècle, 1984
Ce document est protégé par la loi sur le droit d'auteur. L’utilisation des services d'Érudit (y compris la reproduction) est assujettie à sa politique d'utilisation que vous pouvez consulter en ligne.

https://apropos.erudit.org/fr/usagers/politique-dutilisation/
Cet article est diffusé et préservé par Érudit.

Érudit est un consortium interuniversitaire sans but lucratif composé de l’Université de Montréal, l'Université Laval et l'Université du Québec à Montréal. Il a pour mission la promotion et la valorisation de la recherche. https://www.erudit.org/fr/ 


\section{Gulliver Shifts for Himself}

Sartorial tropes are common devices in literary and graphic satires. Ann Messenger's recent essay on clothing imagery in the Henriad traces the satire on tailors, tailoring and fine forms of words back at least as far as the political, philosophical and religious controversies of the English Renaissance. ${ }^{1}$ Ronald Paulson has associated the foppery of the three brothers in $A$ Tale of $A T u b$ with such ludicrous figures as Sir Fopling Flutter, with the travesties of the Restoration stage and graphic caricature. ${ }^{2}$ The limits of the sartorial trope are the shame of nakedness and the absurdity of pomp, which correspond to the bluntness of plainspeaking and the incomprehensibility of euphemism or euphuism. There are symbolical coats, such as Gilray's impoverished John Bull often wears, with trailing tags of referential identity. Such are the allegorical coats of Martin, Jack, and Peter in Swift's most famous sartorial foray allegorical coats, at least according to the learned gloss by Wotton and the tub-thumping Hack. But there are also analogical coats of satire, fabricated by analogical tailors. Instead of symbolizing the products, these mimic the processes of expression and euphemism, thought and delusion. ${ }^{3}$ The Swiftian version of this analogical trope of clothing-andwords is rather less obvious and famous than the symbolical clothesphilosophy and the three brothers' self-tailoring in A Tale of $A$ Tub. The missing analogical tailor is Lemuel Gulliver. What he tailors is a straitjacket of ideas.

The subject of the analogical trope of clothing-and-words - misinterpretation of symbols, confusion of symbol with referent, of vehicle with tenor - reminds us of the particular early occasions of the analogical satire: abuses of the eucharist, of dogma, and of the crown. Studies of 
the Swiftian tailor by Paulson, Philip Harth, Miriam Starkman, and Frances Louis have concentrated on these occasions, have shown that much of the tailoring even in A Tale of $A$ Tub is really analogical, and have defined the realm of unknowing which extends beyond the immediate objects in the satire. It is a realm where accidents usurp essence as the object of knowing, where phenomena pass for noumena, where knowing becomes a mere choice of nice delusions. The denizens of this philosophical mirror-world regard clothing as the true body, words as the nominal reality and exclusive reality. Their truth is a philosophy of clothes, of superficialities - that is, a clothing to hide their philosophical nakedness. The tailor, like the rhetor, lays claim to true philosophy. But his admirable work merely covers and falsifies the body, as the rhetor covers his subject with embellishments which become an end in his art.

In the analogical satire of clothing-and-words, the donning, doffing, and tailoring of clothes follows the ways of expression, interpretation, and thought, and the clothes themselves are not particularly symbolic. Harth, Paulson, and, lately, Louis and Frederick Smith, have treated $A$ Tale of $A T u b$ as a critique of impure reason. ${ }^{4}$ Harth compares the tailorworship and the philosophy of a universe of clothing to the Aeolists' worship of 'wind' as universal principle, and he sees both absurd religions as parodies, hence analogies, of reductive monism in general. Harth comments on the scope of the analogical satire: 'In ridiculing a form of atheism as enthusiastic madness through the reductive system of the tailor-worshippers, [Swift] was simply adopting and turning to his own use a well-established convention of Anglican rationalist polemics against atheists. ${ }^{\text {s }}$ According to Harth, the immediate target of Swift's sartorial analogy is the opening argument of Hobbes' Leviathan, an argument also analogical in its method; the tailor-worshippers' terminology clearly resembles Hobbes'. ${ }^{6}$ The two branches of the tailorworship to which Swift refers are two kinds of materialism. ${ }^{7}$ One kind denies all but the material, sensible reality: if man and the universe are but a suit of clothes, there is no body beneath it (i.e. 'spirit' is really phenomenal). Phenomenon is the only noumen, or else noumen is null. The second kind is traducianism. Its doctrine, in Swift's version, is that 'man was an animal compounded of two dresses, the natural and the celestial suit, which were the body and soul: that the soul was the outward, and the body the inward clothing; that the latter was ex traduce; but the former of daily creation and circumfusion.' 8 The materialists' dependance upon sensations, upon 'the films and images that fly off upon their sense from the superficies of things,' 9 leads them to 'reduce the whole to one of its infinitesimal parts - a part which has a real existence but is of a very limited character. ${ }^{\prime 10}$ 
Paulson unravels the sartorial analogy even more meticulously. He argues that the object of Swift's sartorial satire in A Tale of $A T u b$ is the Gnostic heresy in particular, with an extension to the methods of interpretive and dogmatic self-sufficiency practised in all heresies. Though Paulson grants that the business of the three brothers' coats is allegorical, as Wotton and later glossers allege, ${ }^{11}$ the tendency of Paulson's interpretation of the whole sartorial business in the Tale is to show allegory yielding to analogy. The first mention of the brothers' inheritance and its perversion brings to the Hack's mind a complete philosophy of clothes, and it is this doctrine or method which the embellishment and reformation of coats illustrates. Passing from the allegorical notion of the coats as 'a representation of an external law, the "visible church" - that by virtue of which one is not oneself but part of a community, ${ }^{\prime 2}$ Paulson takes up the meaning of the act of embellishment. ${ }^{13} \mathrm{He}$ moves from the symbolism of coats to the analogy between tailoring and the operations of heretical philosophy. On the analogy of the Renaissance Christian view that the body is the vesture of the soul ... dress is not adornment but part and parcel of the self, an indication of what one is. Ideally, dress and self are mutually informing; but the clothes philosophy to which the brothers yield makes the Gnostic distinction ... between body and soul (reminiscent of the Ramist distinction between form and content). Neither body nor soul can be said to bear any responsibility for the other ... The tailor represents the separation ... between outer and inner, the tendency of the Gnostic mind to think that it can cut the exterior ... to the size of its own vision ... whether by altering the institutional aspects of Christianity or by stripping them away altogether and going naked ... or, in more general terms, that it can change the style with the season. ${ }^{\prime}{ }^{14}$ Louis extends this treatment of $A$ Tale of $A T u b$ as a critique of unreason to Gulliver's Travels, ${ }^{15}$ but she does not develop the analogy between Gulliver's tailoring and his unknowing. It might seem that Swift's amusement with the sartorial trope ended with the virtuoso performance in $A$ Tale of $A T u b$. But there is plenty of tailoring in Gulliver's Travels, and it is entirely analogical, without the allegorical distractions (or the burlesque of the allegorizing pedant) of the Tale.

In Gulliver's Travels there are at least three kinds of tailors. Our attention, however, is not fixed upon their products, as it is upon the three brothers' inherited, elaborated, and reformed coats. We attend, instead, to the means of craftsmanship. The Lilliputian tailors fashion a patchwork container for Gulliver; their looms will make no broader cloth. The tailors of Laputa take Gulliver's measurements indirectly, through plane geometry and trigonometry. In the land of the Houyhnhnms, there are no native tailors, and Gulliver must shift for himself. 
Among the expensive provisions for Gulliver's comfort in Lilliput are the Emperor's orders that 'three hundred tailors should make me a suit of clothes after the fashion of the country.' ${ }^{16}$ In what will become a recurrent matching of the sartorial and the linguistic, these orders are immediately followed in the regal protocol by orders for Gulliver's tutoring in Lilliputian. When Gulliver and his Majesty are able to converse together in some sort' (I, 2, 27) Gulliver's first words 'express my desire that he would please to give me my liberty.' The Emperor frames a polite yet dodgy reply, and begs Gulliver's indulgence if he gave orders to certain proper officers to search me; for probably I might carry about me several weapons, which needs must be dangerous things, if they answered the bulk of so prodigious a person' $(I, 2,27)$. Gulliver is indeed a prodigy for the Lilliputians, yet the Emperor's plan to search his clothing for dangerous weapons shows at once the Lilliputians' acknowledgment and misunderstanding of the prodigy. The body of Gulliver, ignored in the Emperor's polite proposal, is weapon enough, as Gulliver's exploits against the Blefuscan fleet will prove. We see that Gulliver, however, has already put on the cognitive 'fashion of the country,' before the sartorial, for, in order to satisfy his Majesty, he is 'ready to strip myself, and turn up my pockets before him.' Yet he can express this offer only 'part in words, and part in signs' (I, 2, 27). Here, as elsewhere in his account of the travels, Gulliver asserts yet contradicts his linguistic abilities: he recalls, improbably, exact translations of phrases which, at the time he writes about, he could barely utter. The episode closes with a long, finicky inventory of Gulliver's pockets.

The whole episode resolves into patterns of analogy, between the wearing of clothes and the wearing of a system of thought, and between both of these acquisitions and the acquisition of a language. The Lilliputians busy themselves about Gulliver's pockets, but they haven't a proper respect for his person. Moreover, because of the vast differences, between Gulliver and the Lilliputians, in scale of conception, the Lilliputians misconstrue most of what they find in Gulliver's pockets. In the pattern of internal analogies of Gulliver's Travels, such misconstruction of partsand-whole, of details-and-forms, foreshadows Gulliver's dread of the naked female form, whether Brobdingnagian or European or Yahoo, a dread attached first to the stripped serving-women in the court of the Brobdingnagian Queen, a dread later extended to Gulliver's own stripped essence, among the Houyhnhnms.

Gulliver confidently proceeds to trade niceties in an alien tongue, but he doesn't realize that in putting on its forms of words he is also putting on its forms of thought. Thus he proudly shows himself in the fashion of Lilliput well before he describes the tailoring of his garb, and despite the 
fact that the fashion is too small to suit him. Even his offer to strip in order to prove his harmlessness is part of a complicated ironical pattern, like the pattern by which the misconstruction of 'skins' is foreshadowed or analogically reproduced. When the Lilliputians don't take up the offer, Gulliver preserves his privacy by refusing the inspectors entry into three of his pockets, one of them purposefully secret. The latter contains 'a pair of spectacles (which I sometimes use for the weakness of my eyes), a pocket perspective, and several other little conveniences; which, being of no consequence to the Emperor, I did not think my self bound in honour to discover' (I, 2, 30). Gulliver hides the artificial means of sharp vision, perhaps excusing this concealment differently when he remarks of the Lilliputians that 'their sight is much more acute than ours' (I, 2, 30). The spectacles and perspective may suggest near and far sight, as well as the pun on 'spectacle.' Gulliver thinks them of no use to another, but he also appears never to use them with proper skill. Later, Gulliver is thought to have stripped when he has not. The Brobdingnagian farmer, first beholding Gulliver, mistakes Gulliver's coat for his skin; in other words, he thinks that Gulliver is naked. In contrast, Gulliver takes pains to avoid stripping before his master, or any, Houyhnhnm. On the two occasions when his nakedness is exposed in Houyhnhnmland, the results, as we shall notice, are philosophically disastrous.

Unlike the puns upon the tailor's yard and goose in $A$ Tale of $A T u b$ which emphasize sexual prowess or rapacity, ${ }^{17}$ the figures of the tailor and of tailoring in Gulliver's Travels always emphasize the manner of plying the needle, and especially the tailor's incompetence and obliviousness to failure. The other kind of copula-tion is at issue - the engendering of a garment: of words, of concealment. By the method of tailoring we understand the method of philosophy in each realm. The three hundred royally-appointed tailors in Lilliput, for example, may be able to make clothing for Gulliver superficially 'after the fashion of the country,' but neither the finished garments nor the method of manufacture could possibly follow that fashion. It is plain that clothing Gulliver is a major national project, no ordinary task of tailoring. Gulliver keeps careful tally of the manpower devoted to tending him, and the three hundred tailors set to the task may well remind us of the strenuous engineering project of capturing and transporting Gulliver in the first place. The results of both projects are absurd. The Lilliputians can no more encase than really bind Gulliver. Through neither project do they really apprehend him. The packthreads of his captors are better suited to sartorial than military uses, at least according to human scale. The rope of the political rope-jumpers appears to Gulliver merely another such packthread. The 'two hundred sempstresses' who sew his shirts and linen 
employ materials 'all of the strongest and coarsest kind they could get; which, however, they were forced to quilt together in several folds, for the thickest was some degrees finer than lawn' $(I, 6,51)$. Unlike the Laputan tailors, the Lilliputians do bother with Gulliver's measurements, but their ingenuity of plumb-line, ladders, and literal rule-of-thumb is another instance of audacious efforts and puny results: 'my clothes ... looked like the patchwork made by the ladies in England, only that mine were all of a colour' (I, 6, 51). Gulliver apparently rests content with these garments, just as he tests no further the fiction that he is a captive of the Lilliputians. The patchwork garments 'all of a colour' are, like the co-operation necessary to make them, a deceptive, ambiguous matter. They define not only the smaller scale of Lilliputian technology but also the Lilliputians' limited vision, their mastery only of parts, their pettiness. The Lilliputians co-operate to subdue and tend Gulliver, but their natural tendency is factional. They and the Blefuscans wear violently uncomplementary colours of the same religious fabric and differ, of course, about the correct height of heels. When they isolate Gulliver as a faction or cabal of one, a proposal for his assassination is that they poison his shirts and bedclothes. ${ }^{18}$

After the Brobdingnagians discover the difference between Gulliver's skin and his clothing, they try to suit him. The task requires microsurgical dexterity, because Gulliver is tiny even for a Brobdingnagian doll. But the emphasis in this case falls upon the strength of Brobdingnagian cloth, the tailor's success in managing his unaccustomed task, and Gulliver's awkwardness of adaptation: upon the playfulness, not the audacity, of the tailor's effort. Glumdalclitch, the amateur, makes a batch of doll clothing from the finest fabric, which feels to Gulliver 'coarser than sackcloth. ${ }^{\prime 19}$ The Queen's tailor fares slightly better, working with silks 'not much thicker than an English blanket, very cumbersome till I was accustomed to them. They were after the fashion of the kingdom, partly resembling the Persian, and partly the Chinese, and are a very grave decent habit' (II, 3, 84). The discomfort seems Gulliver's, not his hosts'. We suspect that the gravity and the decency of his habit (intended qualities of his rhetoric, too) amuse his hosts, as an animated doll's pretensions might amuse us. Gulliver is quite literally being toyed with.

In short, not the making but the wearing of the clothes is the problem, from the second voyage onward. In Brobdingnag the problem is clearly Gulliver's. Thus the sartorial objects of satire are fixed not in the alien but in the human realm, where they remain for the rest of the Voyages. Most of the occurrences of clothing imagery in the Voyage to Brobdingnag are occurrences of Gulliver's false pride or misconception of 
himself. Gulliver loses his suit of clothes when he tumbles into a cream bowl, pushed by a dwarf. On four other occasions Gulliver befouls his clothing; on the last of these, significantly, while showing off by trying the long-jump over a cow-dung. ${ }^{20}$ Because the radical shift in perspective has put Gulliver on the same scale as frogs, moles, and flies, he cannot keep up outward signs of value: he cannot keep clean. Yet the association of clothing and self-respect takes another turn by the end of the second voyage. Among other evidences of his life as a toy, Gulliver displays proudly 'the breeches I had then on, which were made of a mouse's skin' (II, 8, 119). Considering that, to the Brobdingnagians, Gulliver and the mouse are of equal stature, this display gives a foretaste of Gulliver's uses of Yahoo-skins and of his categorical confusions.

The Laputans and Gulliver regard each other's appearances with shared astonishment. Gulliver describes Laputan 'outward garments' (III, 2,127 ) - an odd yet suggestive redundancy. The garb is 'adorned with the figures of suns, moons, and stars, interwoven with those of fiddles, flutes, harps, trumpets, guitars, harpsichords, and many more instruments of music, unknown to us in Europe' (III, 2, 127). Laputan dishes, he discovers, are similarly carved or contrived (III, 2, 129). The Laputans wear and eat the forms of their conceptual fascinations. Not only are these forms symbolic of inward 'garb' or thought; the methods of fashioning both inward and outward garb are also analogous. We see the analogy in Laputan tailoring. The Laputan tailor measures Gulliver by survey and, it would seem, without touching him. After six days of creation, the tailor brings 'clothes very ill made, and quite out of shape, by happening to mistake a figure in the calculations' (III, 2, 130). This parody of the Creation and of the origination of cosmic evil escapes Gulliver's understanding. He pretends to take comfort from observing 'such accidents very frequent and little regarded' and he soons offers as further palliative the parallel instance of Laputan houses, 'very ill built, the walls bevil, without one right angle in any apartment' (III, 2, 131).

Gulliver explains that 'this defect ariseth from the contempt they bear for practical geometry, which they despise as vulgar and mechanic ... although they are dextrous enough upon a piece of paper in the management of the rule, the pencil, and the divider, yet in the common actions and behaviour of life I have not seen a more clumsy, awkward, and unhandy people, nor so slow and perplexed in their conceptions upon all other subjects, except those of mathematics and music' (III, 2, 131). The limitation is also linguistic: 'Imagination, fancy, and invention, they are wholly strangers to nor have any words in their language by which those ideas can be expressed ...' (III, 2, 131). Gulliver, however, doesn't explicitly assemble these conclusions by coupling unhandiness with 
thoughtlessness or philosophical error. His own habits of mind don't incline him toward such a comparison. Yet accidents are little regarded' in Laputa because Laputans have little regard. The Laputan tailors cannot make simple coverings because they proceed through calculations abstracted from the body. The attempt at figuring (without an underlying figure) is the point of the satire, not the mistake in figuring, which is an irrelevant excuse. Gulliver recognizes the faulty, ludicrous products but not the fallible method of production. There is no right fit of the artificial and the natural, partly, it seems, because the linguistic mediation or pattern is missing. The Laputans, we recall, are singularly oblivious to linguistic signs, hence their need for 'flappers' to signal the very fact of utterance. It should not surprise us that Gulliver witnesses the people of Lagado dressed 'generally in rags ... a people whose countenances and habit expressed so much misery and want' (III, 4, 142). Nor that the first scientific projector whom Gulliver meets in the Academy has 'clothes, shirt, and skin ... all of the same colour,' the colour of soot (III, 5, 145). His madness is visible; he is all of a piece, shameless in asserting his crazed thoughts and in panhandling from Gulliver.

In the land of the Houyhnhnms, neither the rational horses nor the Yahoos are tailors. The Yahoos lack shame and art, the motive and the means. The Houyhnhnms have no conception of clothing. Gulliver bewilders the Houyhnhnm philosophers not only because he seems a clothed Yahoo, a contradiction in terms, but because he is clothed at all, thus a term beyond Houyhnhnm knowledge. When he first beholds a Yahoo and starts to suspect, in horror, a likeness of species with his own, Gulliver notes with fear and relief that the Houyhnhnms do not perceive the likeness between his feet and the Yahoo's 'because of my shoes and stockings' (IV, 2, 186). In contrast, though in similarly delusive philosophical manner, Gulliver is busy ignoring significant differences, such as hairiness, color, skin texture, and length of nails. Gulliver's wearing of gloves is especially puzzling. The master Houyhnhnm signs for him to remove them and 'reduce' his hands 'to their former shape' (IV, 3, 187). This order to expose the reduced shape of the hand is followed immediately, in the now-recognizable sartorial-linguistic match, by an order 'to speak the few words I understood.' In the master's estimation of Gulliver's linguistic prowess there is also a reduction. The juxtaposition of commands is particularly significant in light of the later disclosure that the Houyhnhnms, who have no reason for clothing and therefore tailor none, have no reason for lies and therefore can utter none. For Gulliver's first night among the Houyhnhnms, the master 'ordered a place for me to lodge in; it was but six yards from the house, and separated from the stable of the yahoos. Here I got some straw, and covering myself with 
my own clothes, slept very sound' (IV, 2, 188-189). Gulliver is properly placed apart from both Houyhnhnms and Yahoos, safely slumbering, for the time being, under his own coverings.

But Gulliver's separateness from the Yahoos is ambiguous, as his philosophy of categories breaks down under the pressure of a radically different system - and, no doubt, under the disability of his own unhandiness as philosopher. The master Houyhnhnm 'was convinced ... that I must be a yahoo, but my teachableness, civility, and cleanliness astonished him; ... He was most perplexed about my clothes, reasoning sometimes with himself, whether they were a part of my body; for I never pulled them off till the family were asleep, and got them on before they waked in the morning' (IV, 3, 189). Other Houyhnhnms cannot believe Gulliver 'to be a right yahoo, because my body had a different covering from others of my kind' (IV, 3, 190). Gulliver aggravates the mystery of species, by keeping the secret of my dress, in order to distinguish myself as much as possible from that cursed race of yahoos' (IV, 3, 191). There is a crisis of philosophy, of self-knowledge, when Gulliver is accidentally exposed - while asleep, without his own coverings. A servant Houyhnhnm reports to the master 'that I was not the same thing when I slept as I appeared at other times; ... some part of me was white, some yellow, at least not so white, and some brown' (IV, 3, 191). Like his Lilliputian suit, Gulliver's body appears a patchwork but a patchwork of several shades. When naked he does not seem whole. Of his deliberate self-concealment Gulliver remarks: 'I found it in vain to do so any longer' (IV, 3, 191). The context enforces a pun upon 'in vain' - vanity and futility. Practical Gulliver foresees the latter sense, ignores the former. Soon his clothes will wear out and he will have to tailor for himself, 'by some contrivance from the hides of yahoos or other brutes' (IV, 3, 191). The matching words 'hides' and 'brutes' protect Gulliver from dim suspicions of species kinship and complicity in genocide.

Gulliver decides to explain clothing to the master Houyhnhnm. Thus he accounts for the tailor's art: 'in the country from whence I came those of my kind covered their bodies with the hairs of certain animals prepared by art, as well for decency, as to avoid inclemencies of air both hot and cold' (IV, 3, 191). He offers to demonstrate the difference between clothing and flesh if I did not expose those parts that nature taught us to conceal' (IV, 3, 191). The master, perplexed by the whole idea of clothing, is perplexed especially by Gulliver's claims of decency and natural shame. Houyhnhnms follow the perfectly rational moral imperatives of nature; the nature that dictates shame to Gulliverian yahoos must appear mad. Upon close examination of clothing and flesh, the master Houyhnhnm concludes that Gulliver 'must be a perfect yahoo,' 
despite certain notable exceptions. Yet he allows Gulliver to put on his clothes again, 'for I was shuddering with the cold' (IV, 3, 192). This last sign that clothing may not be merely affectation doesn't influence the master's conclusions, which he repeats in the council held to decide Gulliver's fate in the proposed genocide. In both episodes, Gulliver's sartorial and linguistic traits are noted in tandem. After the master agrees to keep secret the fact of Gulliver's clothing, he next urges that Gulliver 'go on with my utmost diligence to learn their language, because he was more astonished at my capacity for speech and reason than at the figure of my body, whether it was covered or no' (IV, 3, 192). In council, the master mentions clothing and power of speech as first and second items on his list of Gulliver's traits. But just as the master's philosophy has no proper category for Gulliver, so it cannot accommodate the real analogy of clothing and language. The master Houyhnhnm treats speech and reason as a perfect correspondence; he cannot understand how speech may falsify reason, as clothing expands, decorates, conceals the body beneath, as clothing provides secret places. With thought, as with the body, it does matter 'whether it was covered or no.'

The Houyhnhnms' conceptual difficulties with lying and their arguments against the practice, including the argument of their own virtuous example, have often been taken as a simple satire upon human vice. But the sartorial trope suggests otherwise. The master Houyhnhnm's clothing-philosophy, like his philosophy of truth and lies, is adequate to the Houyhnhnm way of life, which is not, and cannot be, the human way. And not all of Gulliver's defence of clothing is unsound. His shivering is eloquent. The Houyhnhnms' philosophy of language holding that language is pure communication because its motives are univalent - is itself a lie about the human reality - and perhaps not even a 'noble lie' such as men would do well to believe. If it is true for Houyhnhnms it is unattainable for men, who need their clothing in order not to freeze or broil to death. Gulliver's lies and disguises are odious, of course, but the Houyhnhnms' absolute truthfulness requires a Houyhnhnm's impervious hide, or a perfect comfort with one's native reality. Swift's very method in Gulliver's Travels, with its multiple ironies and elaborate fictions of authorship and editorship and narrative voice, requiring laborious and significant deconstruction, also gives the lie to Houyhnhnm linguistic philosophy. In a perfect example of that debunking irony at work, Swift has Gulliver report the closing of the master's treatise on the vacant art of lying thus: 'And these were all the notions he had concerning that faculty of lying, so perfectly well understood, and so universally practiced among human creatures' (IV, 4, 194). Whose smugness is this? Is it not the master Houyhnhnm preten- 
ding to be master, too, of the very subject of his ignorance. 'All the notions he had' are notions enough to dismiss the 'faculty.'

The simplicity of the Houyhnhnms' life captivates Gulliver. Over and over he invites us to admire the reduction of ethical complications and conceptual spider-webs to the simple, though static, network of the Houyhnhnms' thoughts and deeds. A Houyhnhnm can ply a needle for show, improbably, but doesn't need the craft; the Houyhnhnms 'have no letters' or alphabet for they have no literature to record. Like Laputans, they are devoid of imagination. Unlike Laputans (or Gulliver), they are also devoid of artifice. The general satirical theme of Chapter VI of the Fourth Voyage is the constrast between European luxuriousness and the natural, unimaginative, unlettered, untechnological existence of the Houyhnhnms. But the particular occasion of the contrast falls within the sartorial trope and therefore subtly alters the direction of the satire. An eleven-year-old Yahoo female sexually attacks Gulliver when she spies him naked, and she howls when he dons his clothing again. This incident is immediately followed by Gulliver's strongest admiration of the nonspeculative, practical, ethical philosophy of the Houyhnhnms. At the moment of sharpest anguish and deepest philosophical confusion, Gulliver seeks a borrowed clarity, which he cannot have.

Gulliver says that at home he carries on his body 'the workmanship of an hundred tradesmen' (IV, 6, 204). The remark brings to mind Swift's frequent attacks, in Gulliver's Travels and in less heavily 'clothed' satires, against imported finery and wasted wealth. ${ }^{21}$ But it also reminds us of the mutual dependencies within society - dependencies which the returned, over-compensating Gulliver can no longer feel or accept with clear conscience. The obverse of the vaunted Houyhnhnm simplicity is that it is easy to lose any member of the community. ${ }^{22}$ When Gulliver must rely upon his own workmanship alone, when he must become his own tailor acording to his own patterns, he works with the skins of creatures whom he partly mistakes for his kin.

Finally, the sartorial trope figures in the most vexatious and important philosophical questions. As is usual with Swift, these questions are chiefly ethical, Is it right to treat creatures variously according to their kind? Are the categories or kinds real? What light reveals them and guides action aright? For ethical purposes, which are the accidental, which the essential, qualities of creatures? Gulliver's clothing somewhat confounds his hosts as they dimly acknowledge the force of such questions. The accidents of the body may similarly confuse our understanding of the spirit which wears the body as its 'outward garb.' The Houyhnhnms' social hierarchy, their scale of ethical value, corresponds perfectly to their various breeds and hues. ${ }^{23}$ Racism is wisdom in Houyhnhnmland, where 
rank is really qualitative. Judgment by 'superficies of things' is wisdom. Gulliver must explain, ironically, that such a method is most unwise when one judges men, among whom the figure of the body belies the figure of the soul. Healthy appearance, among men, betokens vulgarity; weakness or disease betokens nobility of rank. The Yahoos suffer from disease; the Houyhnhnms, perfectly integrated, do not.

The master Houyhnhnm tenders his own clothes-philosophy. It touches upon the fate of the Yahoos and of Gulliver, and it reveals the intellectual 'fashion of the country' in a light not quite as flattering as Gulliver's wholesale admiration and emulation. The Houyhnhnm concedes that he once thought that clothing might be a wise provision for men, in order to prevent hatred among them caused by the sight of bodily deformities. If it preserved social harmony, clothing would be a noble lie. But the master rejects this concession because the source of evil lies deeper - in Yahoos, by his own observation, in men, by Gulliver's account of European politics and history. Hatred is not an aesthetic revulsion. The viciousness of the Yahoos, which results in wars and competition for unworthy objects, like human viciousness arises from 'gross defects in reason, and by consequence, in virtue' (IV, 7, 209). Gulliver would clothe these defects in a fine form of words. 'In order to favour' men, he has 'concealed many particulars, and often said the thing which was not' (IV, 7, 209). Here the master's philosophy fails him. For Gulliver's euphemisms for vice, though excessive and often pathetically futile, nevertheless work in exactly the way that the master would have accepted for clothing. The lies by which Gulliver seeks to ingratiate himself with his present readers not only justify mankind to an alien race; they are also the peaceable lies of community. Remove them altogether and man's nakedness is unbearable; men hate what they behold, even in themselves. Gulliver's 'present' state of antinomian confusion is fair proof of this hypothesis. We remember as well the most infamous victims of anatomy - that radical sort of untailoring - in $A$ Tale of $A T u b$ : the flayed woman and the dissected beau. ${ }^{24}$

Such stripping kills what it reveals, reverses what Carlyle admits as 'the benignant efficacies of concealment. ${ }^{25}$ When Gulliver accepts, admires, and patches into his own, the unhuman, inconsistent philosophy of the Houyhnhnms, he comes to hate men. He even falls into the absurdity of preferring the tender mercies of the savages who wound him without provocation to the generous charity of "European yahoos" who would rescue him.

The Portuguese crewmen of the rescue ship wonder at Gulliver's garb, which, like his shoes, sails, and canoe, he has tailored from the skins of mere brutes: rabbits and yahoos have the same standing as raw 
materials for this tailor's art. ${ }^{26}$ Of this tailoring Gulliver says, with chilling placidity: 'Necessity is the mother of invention'; of its aftermath, that he 'enjoyed perfect health of body and tranquility of mind' (IV, 10, 223). He has his wish - he has become a cool spouter of platitudes, a human parody of Houyhnhnm-hood. But for the tranquility Gulliver pays in confusion, shame, and loathing upon his return to human society. The signs of his condition - and of the shaky sanity of his borrowed philosophy - are largely sartorial. Gulliver refuses to undress aboard the rescue ship. He allows himself to be wrapped up in the Captain's cloak for concealment when they arrive in port, and he accepts a gift of the Captain's fresh shirts, but he refuses to let the Captain's tailor measure him. He says that he fears contamination by Yahoos. But we may suspect that he also fears what the measuring will reveal about his proper figure. It is clear to the rescuers that Gulliver has acquired outlandish garb, foolish ideas, and a barbarous language. Yet Gulliver takes pride in his tailoring. It is a mark of his independence from merely human standards and devices. This very pride, however, is an imperfect imitation of Houyhnhnm-hood, for the horses' language and philosophy hold no notion of pride. Finally, Gulliver admits that it be hard for a man late in life to remove old habits' (IV, 11, 238). The sartorial pun cuts several ways: at the truly 'old habits' of human pride and self-delusion; at the new habits (become old, i.e. trusted) which Gulliver has fashioned for himself; at his 'outward' and inward garb; at his determination to live as a Houyhnhnm, without protective illusions. Like the outraged Swiftian voice behind the projector of 'A Modest Proposal,' Gulliver has suited himself with a garment painful to wear and painful to remove.

\section{MARK MADOFF}

Royal Roads Military College

\section{Notes}

1 Professor Ann Messenger, of Simon Fraser University, has kindly permitted me to read her unpublished paper, " IIll murder all his wardrobe, piece by piece":

Clothing Imagery in I Henry IV.'

2 Ronald Paulson, Theme and Structure in Swift's Tale of A Tub (New Haven, CT: Yale University Press, 1960), p. 27. See also Paulson's reference to the figure of the crazed tailor in The Duchess of Malfi, IV, 2 (p. $110 \mathrm{n}$ ) and to Carlyle's development of a dualism of body-and-clothes in Sartor Resartus, where, according to Paulson, 'a strong preference is shown for the naked body (the soul) over the clothing (the body).' 
3 Paulson (p. 99) carefully unravels the obscure weaving of the pseudo-numinous in the 'Hebrew-like' gibberish of the Gnostic epigraph to $A$ Tale of $A T u b$, with its arbitrary, impressive 'translation' attached: 'On the threshold of the Tale, it is a symbol of the sufficiency which goes so far as to create its own religion and language.' Paulson directs a student of the sartorial analogy to Swift's burlesque treatise On the Mechanical Operation of the Spirit, wherein a quilted cap prevents evaporation of perspiration except by mouth (words=excreta): '... communication can be either the result of a digestive process or of a mental process. The "Manufactory Operation" of the tailor and the "drawing and spinning" of the spider both suggest the mindless nature of the former' (p. 119).

4 Philip Harth, Swift and Anglican Rationalism: The Religious Background of "A Tale of A Tub" (Chicago: University of Chicago Press, 1961); Paulson, op. cit.; Frederick N. Smith, Language and Reality in Swift's "A Tale of a Tub" (Columbus: Ohio State University Press, 1979); Frances D. Louis, Swift's Anatomy of Misunderstanding: A Study of Swift's Epistemological Imagination in "A Tale of $A$ Tub" and "Gulliver's Travels" (New York: Barnes \& Noble, 1981); Miriam Starkman, Swift's Satire on Learning in "A Tale of A Tub" (New York: Octagon, 1968).

5 Harth, p. 80.

6 Harth, p. 85.

7 Harth, pp. 82-83.

8 Jonathan Swift, $A$ Tale of $A$ Tub, in Gulliver's Travels and Other Writings, ed. Louis A. Landa (Boston: Houghton Mifflin-Riverside, 1960), p. 283 (Section II).

9 Edward Stillingfleet, Origines Sacrae (7th ed.; Cambridge, 1702) quoted in Harth, p. 140.

10 Harth, p. 142.

11 Paulson, p. 27.

12 Paulson, p. 106

13 The Gnostics ... created a metaphor by simply giving a thing a name that belongs to something else. By this system any name and object can be associated at will' (Paulson, p. 142). Paulson draws examples of this procedure of 'secret analogy' from the Hack's metaphors (p. 143), and explains (p. 142) that one of the three intellectual methods required for reading the Tale sanely is a sense of 'common analogy' or of public, not esoteric, metaphorical significances.

14 Paulson, pp. 109-110.

15 Louis's valuable discussion of epistemological analogies in both satires centres upon the likenesses between physical size, percedptual apparatus, magnanimity, and ethical wisdom.

16 Jonathan Swift, Gulliver's Travels, in Gulliver's Travels and Other Writings, ed. Louis A. Landa (Boston: Houghton Mifflin-Riverside, 1960), p. 26 (I, 2, 26). All subsequent citations from $G T$ will be given within parentheses in the text, in the format (Book, Chapter, page number in Landa's edition).

17 Paulson (p. 199) explains 'goose' as sexual favor or sexually available woman, 'yard' as sexual organ, 'seamen' obviously as its homophone, and 'needle' as an undermining description of the size of the phallus. 
$18 G T, I, 7,56$.

19 GT, II, 2, 77. This case of relativity in perception (what seems fine in texture to the Brobdingnagians seems coarse to Gulliver) does not deny the stability of the object of sense. But when the objects of sense are animate (e.g. persons), the epistemological crux is complicated by the intrusion of blame: '... a very ofensive smell came from their skins; which I do not mention or intend to the disadvantage of those excellent ladies, for whom I have all manner of respect; but I conceive that my sense was more acute in proportion to my littleness. ... Upon this point, I cannot forebear doing justice to the Queen my mistress, and Glumdalclitch my nurse, whose persons were as sweet as those of any lady in England' (II, 5, 94). The final comparison ironically leaves open the question of blame and of the stability of sensory objects.

20 The cream-bowl incident occurs at II, 3, 87. In the incident of the marrowbone (II, $3,87-88$ ) Gulliver soils his stockings and breeches. He ruins his suit through a fall into a mole-hill at II, 5, 94, and is befouled by frog slime at II, 5, 97. The cowdung leap occurs at II, 5, 100.

21 A striking and famous example of the damning list occurs at IV, 6, 203: 'But in order to feed the luxury and intemperance of the males, and the vanity of the females, we sent away the greatest part of our necessary things to other countries, from whence in return we brought the materials of disease, folly, and vice, to spend among ourselves. Hence it follows of necessity that vast numbers of our people are compelled to seek their livelihood by begging, robbing, stealing, cheating, pimping, forswearing, flattering, suborning, forging, gaming, lying, fawning, hectoring, voting, scribbling, star-gazing, poisoning, whoring, canting, libelling, free-thinking, and the like occupations: every one of which terms, I was at much pains to make him understand.' The list is luxuriously illustrative, yet there are holes in its fabric: 'voting,' 'star-gazing,' and 'free-thinking' are odd entries. Having elaborated so many unfamiliar terms, for unfamiliar deeds, Gulliver both takes and suffers pains to interpret.

22 IV, 9, 221. 'Friendship and benevolence are the two principal virtues among the Houyhnhnms, and these not confined to particular objects, but universal to the whole race. ... They have no fondness for their colts or foals, but the care they take in educating them proceeds entirely from the dictates of reason' (IV, 9, 216). Gulliver registers this stoicism coolly. If he admires it, he does so quietly, through understatement.

23 The confusion of accident and essence is plainly a feature of the debate in the grand council of the Houyhnhnms to adopt a modest proposal about the Yahoo/Gulliver problem. The arguments have the manner of formal logical soundness, but the propositions about Gulliver's body, intellect and kind do not yield valid conclusions. Houyhnhnm racism (IV, 6, 207) matches Houyhnhnm eugenic marriage customs (IV, 8, 217).

24 Swift, $A$ Tale of $A$ Tub, ed. Landa, p. 333. The Hack's verb connects clothing and dissection: Yesterday I ordered the Carcass of a Beau to be stript in my Presence; when we were all amazed to find so many unsuspected Faults under one Suit of Cloaths: Then I laid open. ...' Dissection is a continuation of stripping.

25 Thomas Carlyle, Sartor Resartus (London: Dent, 1908), p. 174 (Book III, Chapter III, 'Symbols'). I am grateful to Professor Murray J. Evans of the University of 
Winnipeg for directing me to an analysis of the ethics of truth-telling and concealment which resembles my own. In his letter to Eberhard Bethge of 5 December 1943, Dietrich Bonhoeffer turns to the sartorial-linguistic analogy as a means of ethical clarification: 'After all, "truthfulness" does not mean uncovering everything that exists. God himself made clothes for men; and that means that in statu corruptionis many things in human life ought to remain covered, and that evil, even though it cannot be eradicated, ought at least to be concealed. Exposure is cynical, and although the cynic prides himself on his exceptional honesty, or claims to want truth at all costs, he misses the crucial fact that since the fall there must be reticence and secrecy.' - Letters and Papers from Prison, ed. Eberhard Bethge (enlarged edition, London: SCM Press, 1967), p. 158. See also pp. 212-213, and the remark (p. 288): 'There are few people who know how to value reticence,' and Bonhoeffer, Ethics, ed. Eberhard Bethge (London: Fontana, 1964), Part Two, Chapter V, What is Meant by "Telling the Truth"?'

26 GT, IV , 10, 223 \& 227. 